\title{
Patterns of biological invasions in French freshwater systems by non-indigenous macroinvertebrates
}

\author{
Simon DEVIN ${ }^{1 *}$, Loïc BOLLACHE ${ }^{2}$, Pierre-Yves NOËL ${ }^{3}$ and Jean-Nicolas \\ BEISEL $^{1}$ \\ ${ }^{1}$ Université de Metz - UFR SciFA - Laboratoire Biodiversité et Fonctionnement des \\ écosystèmes - Campus Bridoux, Av. du Gén. Delestraint, 57070 Metz, France \\ ${ }^{2}$ Equipe Ecologie Evolutive, UMR CNRS 5561 Biogéosciences, Université de Bourgogne, \\ 6 boulevard Gabriel, 21000 Dijon, France \\ ${ }^{3}$ Muséum National d'Histoire Naturelle, Département Milieux et Peuplements \\ Aquatiques, UMR CNRS-UPMC-MNHN BOME 5178, 55 rue Buffon, 75005 PARIS, \\ France
}

Key words: biological invasions, exotic species, freshwater macroinvertebrates, French aquatic ecosystems

\begin{abstract}
Freshwater biodiversity is threatened by several mechanisms, of which the introduction of non-indigenous species and habitat alteration are the two most important. Exotic species act at various levels of organisation of macroinvertebrate communities, and are involved in different processes mediating their impacts on biodiversity, such as habitat modification or negative interactions with autochthonous fauna. The present work gives a list of the 43 French freshwater non-indigenous species, which represent $1.2 \%$ of the French freshwater acroinvertebrates. We provide their geographic origins, their distributions among zoological units by comparison with the native fauna and their functional characteristics according to a recent typology based on bio/ecological traits. An exponential trend of the cumulated number of non-indigenous species was evidenced, with a clumping of invaders within crustaceans and molluscs. Donor areas of non-indigenous species are in majority European, and the PontoCaspian basin is identified as the principal one. This pattern could be explained by a spread along waterways but its origin lies in a process of recolonisation of defaunated areas following several episodes of glaciation / deglaciation in Western Europe during the last 80,000 years. Finally, from a functional point of view, non-indigenous species exhibit a limited diversity, with two functional groups representing $80 \%$ of them.
\end{abstract}

\section{Introduction}

Biodiversity is not a static dimension that could be defined once and for all, but is, on the contrary, permanently changing, influenced by natural and anthropic processes. Among this last category, biological invasions are now considered to be a major driver of change of freshwater biodiversity (Sala et al., 2000).

Invasions consist of the transfer, establishment and spread of a species within an ecosystem where it is not naturally present, also called the recipient ecosystem (Vermeij, 1996; Williamson, 1996; Kolar \& Lodge, 2001). In a strict sense, the introduction of non-indigenous species occurs naturally, and is not exclusively a human-driven phenomenon (Mack et al., 2000). However, a growing interest is accorded to the human-mediated invasions, since increasing rates of species establishment have been observed these last decades in many 
aquatic ecosystems (The Great Lakes, Ricciardi, 2001; San-Francisco Bay, Cohen \& Carlton, 1998) as a consequence of the removal of natural geographic barriers and the expanding transport by waterways. The disappearance of autochthonous species in human-altered freshwater ecosystems, the poverty of the fauna remaining and their inability to adapt to new local conditions (Sax and Brown 2000) have favored the permeability of to repeated introductions of exotic species (decrease in biotic resistance as defined by Elton 1958). Many impacts of invaders have been referenced, and among them the threat for biodiversity they represent (Sala et al., 2000; Mooney \& Cleland, 2001; Rahel, 2002). Effectively, invasive species can have major ecological consequences on faunal composition, community structure and ecosystem functioning (Mack et al., 2000). All these impacts are mediated by numerous processes that act at various levels of organisation, from the individual to the community as a whole (Simon \& Townsend, 2003).

In many countries, biological invasions are heavily studied, with national databases on non-indigenous species present, their dynamics, distributions and impacts (Leppäkoski et al., 2002). When performed for freshwaters at a large scale (bij de Vaate et al., 2002; Leppäkoski et al., 2002), such studies do not take into account French territory. However, thanks to the high diversity of French ecoregions, non-indigenous species already referenced in southern, eastern and northern Europe could potentially be found there. Moreover, with regards to its geographic position and its high connectivity with main European waterways and other continents due to the presence of many harbours (Bordeaux, Le Havre, Marseille-Fos, NantesSaint-Nazaire, Rouen), France could constitute an important platform of fauna exchange. The territory includes six main basins, corresponding to the largest rivers: Garonne, Loire, Seine, Rhone, Meuse and the upper Rhine. Several streams along the Atlantic coast directly flow to the ocean and are not connected to one of the main rivers. Several rivers (Rhone, Meuse, Rhine) flow across several countries.

The present study aims to make an inventory of non-indigenous species observed in French aquatic ecosystems and to analyse their geographic origin, their distribution among freshwater fauna and their functional position according to a typology based on bio/ecological traits (Usseglio-Polatera et al., 2001). These results are discussed in terms of non-indigenous species origins and potential consequences of introductions.

\section{Material and methods}

Based on a huge bibliographic analysis, we documented the non-indigenous species that could be found in French freshwater systems. Only free-living macroinvertebrates were considered in this study, i.e. parasites and invertebrates below 3-5 $\mathrm{mm}$ in their adult size (microinverbertebrates as defined by Tachet et al., 2000) were excluded. Data on nonindigenous species are quite difficult to collect based on the bibliography. French national agencies perform bioassessment using a global method that requires identification to the family level only, thus are unable to provide such data. Moreover, very few articles deal with species introductions in French aquatic ecosystems, and when available, such information is often published in local society of natural history bulletins, which are difficult to obtain.

Thus we kept only data signalling a new species if at least one scientific article is available (i.e. referenced in an international review or in a national review included in PASCAL database). For each species, we defined the date of the first observation, its origin and its major ecological and biological characteristics. Species distribution among the major French basins is estimated with bibliography, but it does not always reflect the true distribution. Consequently, it will not be possible to describe the dynamics of colonisation and dispersal of non-indigenous species within French aquatic ecosystems. For most of the species, vector of introduction is not known, even if numerous studies have already detailed 
the major role of shipping traffic, and particularly ballast water transport, in the spread of aquatic exotic species throughout the world (see Gollash et al., 2002 for a review).

The functional classification recently developed for benthic macroinvertebrates based on both biological and ecological traits (Usseglio-Polatera et al., 2001) was used to assess the main characteristics of non-indigenous species. This classification has lead to the definition of 6 functional groups, 9 subgroups and 43 units according to a biological versus ecological ordination. For species not referenced before, P. Usseglio-Polatera performed a new analysis that allowed us to integrate and classify them. The present study is based on the subgroup level and French non-indigenous species belong to 6 of them (called $\beta, \delta 1, \delta 2, \gamma 1, \gamma 2$ and $\zeta$ by Usseglio-Polatera et al., 2001). Most species of the group $\beta$ exhibits small to medium sizes, an omnivorous regime and a scraper or shredder feeding behaviour. They live in coarse mineral substrates and are oligo to $\beta$-mesosaprobic. Groups $\delta 1$ and $\delta 2$ shared many characteristics, such as living on organic substrates and being $\beta$-mesosaprobic. They tend to be predator, feeding on macroinvertebrates, and exhibit small to medium sizes. Species of the groups $\gamma 1$ and $\gamma 2$ live on mineral or organic substrates and are $\beta$-mesosaprobic. The feeding habits of these medium-sized taxa are similar to that of group $\beta$. Finally, group $\zeta$ is constituted of filter- or deposit-feeders that fed on microphytes and fines detritus, with variable body sizes and microhabitat preferences. All taxa of these 6 functional groups are eurythermous.

Finally, the proportion of non-indigenous species among the different zoological units that could be found in French rivers was analysed in order to assess whether some taxa have greater roles in biological invasions than others. Nematomorpha were excluded, because we did not get enough data to reliably estimate the proportion of non-indigenous species within this group. All species occurring in surface freshwaters were taken into account for this analysis.

\section{Results}

\section{A major phenomenon}

As a whole, 43 non-indigenous species have been recorded within French aquatic ecosystems. It is difficult to identify the first species that invaded these hydrosystems, because the knowledge and the study of freshwater macroinvertebrates is not an old discipline. However, the history of species establishment can be made for the last 175 years, beginning with the description of Atyaephyra desmaresti in the Loire basin in 1832 (Dhur \& Massard, 1995), and Gammarus roeseli in the vicinity of Paris in 1835 (Jazdzewski, 1980) (Table 1). Since these dates, new species in French freshwater fauna have been identified regularly. The actual trend of invasion, if we consider the whole territory, could be described by a highly significant exponential function (Fig. 1), suggesting an acceleration of the phenomenon in the last few decades.

\section{Geographic origin of non-indigenous species and distribution}

Species introductions are strongly dominated by intra-continental transfers (25 of 43 species are of European origin, Table 1). Among the three European donor areas identified, we notice that the Ponto-Caspian basin distinguishes itself $(32.5 \%$ of whole non-indigenous species, $58 \%$ of those with a European origin), and confirms its status as a hot-spot donor area of non-indigenous species. The two others main donor areas are North America and SouthEastern Asia. It is noteworthy that, excepting Potamopyrgus antipodarum, all non-indigenous species came from the northern hemisphere.

The description of the present distribution of non-indigenous species in France represents a hard task. As signalled in the introduction, few data are available for each basin. 
The Rhine basin is better studied than the others, and exotic species arrivals are particularly well documented there, due both to its position among Western Europe waterways and numerous programs of rehabilitation. The Rhone basin is second in terms of available data concerning macroinvertebrates communities. It is harder to get detailed information for basins such as that of the Loire and Garonne rivers.

\section{A strong dissymmetry between taxa}

To date, $1.2 \%$ of French freshwater macroinvertebrates is of exotic origin considering species introduced in the past 200 years. Those non-indigenous species could be found among almost all taxonomic groups. However, some of them are more implicated in biological invasions than others (Table 2). Considering the species number, two groups distinguish themselves: molluscs and crustaceans, that represent respectively $26 \%$ and $49 \%$ of all nonindigenous species found in French hydrosystems.

We also notice that non-indigenous species are represented among all zoological units, except Porifera, a weakly diversified group. The most diverse group of freshwater invertebrates, the insects, is the one were the proportion of exotics is the lowest. Conversely, freshwater Polychaeta are only represented by the non-indigenous taxon Hypania invalida. Molluscs and Crustaceans excepted, it seems that no taxonomical clumping of non-indigenous species occurred.

Finally, for 36 species only the functional group is known. The large majority of nonindigenous species belong to two bio/ecological groups: $\gamma 2$ and $\zeta$ (respectively 9 and 19 species in each group). Four other functional groups are represented, but by a lower number of species ( 2 species in each group), and, except for group $\beta$, by species that do not have spectacular population explosions within French freshwater systems (see Table 1 for species and references).

\section{Discussion}

All freshwater fauna of France could be considered as non-indigenous, going back in time enough, to the last glaciations. During the Würm glaciation (80,000-10,000 BP), the major part of Western Europe was covered with ice. Thus, at the end of this period, defaunate freshwater ecosystems appeared, colonised or recolonised by species having survived in refuge areas that were outside ice range extension (according to Oberdorff et al., 1997). We can not define whether a recolonisation or a colonisation process occurred (i.e. did the species were the same before and after the glaciations or not?), because the fauna present before the Würm glaciation is poorly known (few invertebrate fossil records). The two main refuge areas in Europe are Mediterranean Europe and the Danube basin (Persat \& Keith, 1997). The process of colonisation, which is well documented for fish, probably also took place for macroinvertebrates.

Thus, the dominant pattern of invasion could be assimilated to a colonisation process of defaunate areas as an inheritance of the last glaciation, with Eastern Europe being a provider of non-indigenous species and Western Europe as a recipient area. This process could be illustrated with the establishment of many Ponto-Caspian amphipod species in France. Based on the data provided by the Limnofauna Europea (Illies, 1978), 23 autochthonous species could be found in France, 7 of them inhabiting essentially brackish waters and 10 being restricted to small geographic areas in southern France. Thus, amphipod assemblages are essentially constituted of 6 species versus 63 in the Ponto-Caspian basin: this dissymmetry could be explained by an original pattern of amphipod invasions along a longitudinal European gradient from East to West. Another consequence of this geological 
history of Western Europe is that the only solid basis to study changes in freshwater fauna is the oldest faunal list available for a given biota.

However, an acceleration is observed in non-indigenous species establishment within French aquatic ecosystems during the last few decades, suggesting that besides a natural process of colonisation, a human-mediated transport of species was essential and occurred in Europe (van der Velde et al., 2000, bij de Vaate et al., 2002). Nevertheless, the acceleration of this process could also be an artefact, related to the growing interest attached to biological invasions, and variations in sampling effort among years (Delisle et al., 2003).

The identification and distribution of invasive species in France also lead to the difficult problem of species range extension assessment. Among them, some are naturally present within French hydrosystems, such as the Mediterranean Proasellus coxalis or Atyaephyra desmaresti. The difficulty in such cases consists in determining where the natural area of a species stopped, and where it should be considered as non-indigenous. It represents a very hard task because the spread can be very slow, and observations are generally only reported when species colonise rivers largely outside their natural range (i.e. once they have colonised another basin).

The 43 non-indigenous species identified represent more than one percent of the total macroinvertebrate French freshwater fauna. However, they could represent much more in terms of density ( $23 \%$ in species number, $88 \%$ in abundance in the Moselle River, a tributary of the Rhine River; Devin et al., in press). In French aquatic ecosystems, non-indigenous crustaceans and molluscs have met with more success than other taxa. Such clumping of invaders occurs elsewhere (Morton, 1997; Van der Velde et al., 2000) because closely related species tend to share traits that promote a successful introduction (Devin \& Beisel, unpublished data). Moreover, molluscs and crustaceans are holobiotic species present all year round in the water and are generally represented in term of density and widely distributed in their natural ranges. These characteristics magnify their probability to be transported in a new ecosystem thanks to human activities (the human commensalism evoked by Ricciardi \& Rasmussen, 1998).

This raises the problem of introduction vectors, not considered in the present analysis because precise data on vectors are scarce. For intercontinental transfers, aquatic species could mostly be transported by ballast water or for aquaculture purpose. For intracontinental transfers, besides these two vectors, recreational shipping and natural migration along newly opened waterways could also occur. However, while a mix between the different vectors should more probably be evoked, shipping and natural migration should constitute the most important vectors, in regard to the migratory corridor identified (bij de Vaate et al., 2002).

Among non-indigenous species, six have been particularly successful and are of particular concern for freshwater biodiversity and ecosystem functioning: Craspedacusta sowerbyi, Dreissena polymorpha, Corbicula fluminea, Dikerogammarus villosus, Chelicorophium curvispinum and Orconectes limosus. They represent $13.9 \%$ of the nonindigenous fauna, a value that fits with the tens rule of Williamson (1996), stating that an average of one in ten successful introduced species will become invasive. The main characteristics of these species have already been detailed in several articles (van der Velde et al., 2000, bij de Vaate et al., 2002), as well as their ecological and economical impacts (van der Velde et al., 2000, Westman, 2002, Simon \& Townsend, 2003).

The main consequences of non-indigenous species in French freshwaters could be divided into several categories, and can lead to:

- a significant contribution in the oxygen budget of the river by filter activities of species such as the non-indigenous molluscs D. polymorpha and Corbicula sp. (Bachmann et al., 1998) 
- modifications of nutrient flux due to the filtration activity and pseudofeces production of bivalves, that cause the phenomenon of biodeposition (Botts et al., 1996; MacIsaac, 1996; Hakenkamp et al., 2001)

- transport and dissemination of parasites by species such as Orconectes limosus spreading the crayfish plague on colonised hydrosystems (Laurent, 1997; Van der Velde et al., 2000)

- competition for space between the autochthonous amphipod Gammarus pulex and the two invasives G. tigrinus and Dikerogammarus villosus (Devin et al., 2003)

- predation upon both native and non-indigenous fauna by introduced species with a predatory behavior such as D. villosus (Dick \& Platvoët, 2000; Dick et al., 2002)

- modification of the structural features of the habitats by fouling species, such as $D$. polymorpha and Chelicorophium curvispinum (Bachmann et al., 2001) or ecosystem engineers such as crayfish (Statzner et al., 2000).

This broad spectrum of impacts raises the need for predictive tools of ecosystem modifications in response to the establishment of non-indigenous species.

Finally, from a biological and ecological point of view, our results are in accordance with those of bij de Vaate et al. (2002): non-indigenous species are dominated by predators and filter feeders, and are generally thermophilous and euryhalines. The proportion of nonindigenous species among the different functional groups fits with their proportions among the main taxonomical units presented in the Table 2. However, species belonging to the groups $\zeta$ and $\gamma 2$ could be found among almost all taxonomical units. Thus, it seems that a high majority of non-indigenous species exhibit similar functional characteristics and that, more than a taxonomical clumping, a functional clumping of non-indigenous species take place, which evidenced that particular bio/ecological profiles could enhance invasiveness. Moreover, as previously discussed, most of the non-indigenous species come from the PontoCaspian basin. The complex and long evolution of this basin, with a highly variable salinity and temperature, and a high degree of endemism resulting from a long isolation, has led to a selection of euryecious species (Dumont, 1998; Reid \& Orlova, 2002) presenting adequate features for a human-aided inoculation in new ecosystems.

A consequence of these similar functional characteristics of non-indigenous species is that, besides a threat to biodiversity in term of species composition, it could bring about functional redundancy (as defined by Rosenfeld, 2002) within macroinvertebrate communities.

\section{Acknowledgements}

This study was supported by the French Ministry of Ecology and Sustainable Development, as part of the 2003-2005 INVABIO - Biological Invasions Program.

\section{References}

André, M. (1934): Sur une écrevisse américaine pullulant aux portes de Paris. - C. R. Acad. Sci., Paris 199: 538539.

Anonymous, 2002. Le macrozoobenthos du Rhin 2000. Commission Internationale pour la Protection du Rhin.

Arvy, L. (1972): Sur la présence de Craspedacusta sowerbyi Lankester, 1880 (Limnoméduse: Olindiidae), associé à un commensal (Trichodinia pediculus Ehrenberg, Cilié: Peritrichia) dans le canal de Briare. Ann. Sci. Nat. - Zool. Biol. An. 14: 131-146.

Bachmann, V., J. N. Beisel, P. Usseglio-Polatera.\& J. C. Moreteau (2001): Decline of Dreissena polymorpha in the River Moselle: biotic and abiotic key factors involved in dynamics of invasive species. - Arch. Hydrobiol. 151: 263-281.

Bachmann, V., P. Usseglio-Polatera, E. Cegielka, P. Wagner, J. F. Poinsaint \& J. C. Moreteau (1997): Premières observations sur la coexistence de Dreissena polymorpha, Corophium curvispinum et Corbicula spp. dans la rivière Moselle. - Bull. fr. Pêche Piscic. 344/345: 373-384. 
Bachmann, V., P. Usseglio-Polatera, J. C. Moreteau \& P. Wagner (1998): A new method to assess the contribution of the macrobenthic compartment to the dissolved oxygen budget of a large river. - In: Bretschko, G. \& Helesic, J. (eds.): Advances in river bottom ecology. - Backhuys Publishers, Leiden, pp. 143-153.

bij de Vaate, A., K. Jazdzewski, H. A. M. Ketelaars, S. Gollasch \& G. Van der Velde (2002): Geographical patterns in range extension of Ponto-Caspian macroinvertebrates species in Europe. - Can. J. Fish. aquat. Sci. 59: 1159-1174.

Boettger, C. R. (1954): La distribution actuelle de Potamopyrgus jenkinsi (E.A. Smith) en France. - Journal de Conchyliologie 94: 31-38.

Bollache, L., S. Devin, R. Wattier, M. Chovet, J. N. Beisel, J. C. Moreteau \& T. Rigaud (2004): Rapid range extension of the Ponto-Caspian amphipod Dikerogammarus villosus in France: potential consequences. - Arch. Hydrobiol. 160: 57-66.

Botts, P. S., B. A. Patterson \& D. W. Schloesser (1996): Zebra mussel effects on benthic invertebrates: physical or biotic? - J. N. Am. Benthol. Soc. 15: 179-184.

Charmantier, G. (1992): Occurrence of freshwater crabs, genus Potamon, in southern France. - J. Crust. Biol. 12: 620-626.

Cohen, A. N. \& J. T. Carlton (1998): Accelerating invasion rate in a highly invaded estuary. - Science 279: 555558.

Delisle, F., C. Lavoie, M. Jean \& D. Lachance (2003): Reconstructing the spread of invasive plants: taking into account biases associated with herbarium specimens. - J. Biogeogr. 30: 1033-1042.

Devin, S., J. N. Beisel, V. Bachmann \& J. C. Moreteau (2001): Dikerogammarus villosus (Amphipoda: Gammaridae): Another invasive species newly established in the Moselle River and French hydrosystems. - Ann.Limnol. 37: 21-27.

Devin, S., J. N. Beisel, P. Usseglio-Polatera \& J. C. Moreteau. Changes in functional biodiversity in an invaded freshwater ecosystem: the Moselle River. - Hydrobiologia in press.

Devin, S., C. Piscart, J. N. Beisel \& J. C. Moreteau (2003): Ecological traits of the amphipod invader Dikerogammarus villosus on a mesohabitat scale. - Arch. Hydrobiol. 158: 43-56.

Dhur, G. \& J. A. Massard (1995): Etude historique et faunistique des Invertébrés immigrés ou introduits dans la Moselle luxembourgoise et ses affluents. - Bull. Soc. Nat. lux. 127-156.

Dick, J. T. A. \& D. Platvoet (2000): Invading predatory crustacean Dikerogammarus villosus eliminates both native and exotic species. - P. Roy. Soc. Lond. B Bio. 267: 977-983.

Dick, J. T. A., D. Platvoet \& D. W. Kelly (2002): Predatory impact of the freshwater invader, Dikerogammarus villosus (Crustacea: Amphipoda). - Can. J. Fish. aquat. Sci. 59: 1078-1084.

Dumont, H. J. (1998): The Caspian Lake: history, biota, structure, and function. - Limnol. Oceanogr. 43: 44-52.

Elton, C.S. (1958): The Ecology of Invasions by Animals and Plants. - Univ. of Chicago Press, London.

Fontan, B. \& J. Meny (1997): Note sur l'invasionde Corbicula fluminea dans le réseau hydrographique de la région Aquitaine et précisions sur son spectre écologique. - Vertigo 7: 31-44.

Girardill, O. \& J. C. Ledoux (1989): Présence d'Anodonta woodiana (Lea) en France (Mollusques, Lamellibranches, Unionidae). - Bull. mens. Soc. linn. Lyon 58: 286-292.

Godron, D. A. (1862): Zoologie de Lorraine ou catalogue des animaux sauvages. - Mémoires de l'Académie Stanislas, Nancy.

Gollasch, S., E. MacDonald, S. Belson, H. Botnen, J. T. Christensen, J. P. Hamer, G. Houvenaghel, A. Jelmert, I. Lucas, D. Masson, T. McCollin, S. Olenin, A. Persson, I. Wallentinus, L. P. M. J. Wetsteyn \& T. Wittling (2002): Life in ballast tanks. - In: Leppäkoski, E., Gollasch, S., \& Olenin, S. (eds.): Invasive aquatic species of Europe. Distribution, Impacts and Management. - Kluwer Academic Publishers, Dordrecht, The Netherlands, pp. 217-231.

Goy, J. (1971): La méduse Craspedacusta sowerbyi Lankester 1880, en France. - Bull. Soc. zool. Fr. 96: 17-22.

Hakenkamp, C. C., S. G. Ribblett, M. A. Palmer, C. M. Swan, J. W. Reid \& M. R. Goodison (2001): The impact of an introduced bivalve (Corbicula fluminea) on the benthos of a sandy stream. - Freshwat. Biol. 46: 491-501.

Henry, J. P. \& G. Magniez (1983): Introduction de l'Aselle Proasellus coxalis (Crustacé Isopode Asellote) dans une sablière près de Dijon. - Bull. sci. Bourg. 36: 43-48.

Hoffman, J. A. (1964): Faune des Triclades paludicoles du Grand-Duché de Luxembourg. - Archives de l'Institut Grand-Ducal de Luxembourg 30: 181-261.

d'Hondt, J. L. \& B. Condé (1996): Une espèce de Bryozoaires d'eau douce (Phylactolaemates) nouvelle pour la faune française : Pectinatella magnifica (Leidy, 1851). - Bull. mens. Soc. linn. Lyon 65: 322-326.

Illies, J. (1978): Limnofauna Europaea. - G. Fischer Verlag, Stuttgart.

Jazdzewski, K. (1980): Range extension of some Gammaridean species in European inland Waters caused by human activity. - Crutaceana Suppl. 6: 84-107. 
Kinzelbach, R. (1972): Einschleppung und Einwanderung von Wirbellosen in Ober- und Mittelrhein. - Mainzer Naturwissenchaftliches Archiv 11: 109-150.

Kinzelbach, R. (1992): The main features of the phylogeny and dispersal of the zebra mussel Dreissena polymorpha. - In: Neumann, D. \& Jenner, H. A. (eds.): The zebra mussel Dreissena polymorpha. Gustav Fischer Verlag, Stuttgart, Vol. 4, pp. 5-17.

Kolar, C. S. \& D. M. Lodge (2001): Progress in invasion biology: predicting invaders. - Trends Ecol. Evol. 16: 199-204.

Laurent, P. J. (1997): Introductions d'écrevisses en France et dans le monde, historique et conséquences. - Bull. fr. Pêche Piscic. 344/345: 345-356.

Lécureuil, J. Y. \& M. Chovet (2003): Connexion entre les bassins hydrographiques européens et dissémination des espèces aquatiques : le cas de la Loire moyenne. - Symbioses 9: 25-31.

Léglize, L. \& M. Ollivier (1981): Mise au point bibliographique sur la biologie et l'écologie de Dreissena polymorpha Pallas (1771): répartition géographique en France et dans les pays limitrophes. EDF/DER Rapport HE/31-81.37.

Leppäkoski, E., S. Gollasch \& S. E. Olenin (2002): Invasive aquatic species of Europe. Distribution, Impacts and Management. - Kluwer Academic Publishers, Dordrecht, The Netherlands.

MacIsaac, H. J. (1996): Potential abiotic and biotic impacts of zebra mussels on the inland waters of North America. - Am. Zool. 36: 287-299.

Mack, R. N., D. Simberloff, W. M. Lonsdale, H. Evans, M. Clout \& F. Bazzaz (2000): Biotic invasions: causes, epidemiology, global consequences and control. - Issues in Ecology 5: 22pp.

Mooney, H. A. \& E. E. Cleland (2001): The evolutionary impact of invasive species. - Proc. Natn. Acad. Sci. U.S.A. 98: 5446-5451.

Morton, B. (1997): The aquatic nuisance species problem: a global perspective and review. - In: D'Itri, F. (ed.): Zebra mussels and aquatic nuisance species. - Ann Arbor Press, Chelsea, Michigan, pp. 1-53.

Mouthon, J. (1981): Sur la présence en France et au Portugal de Corbicula (Bivalvia, Corbiculidae) originaire d'Asie. - Basteria 45: 109-116.

Mouthon, J. (1986): Emmericia patula (Gasteropoda, Emmericiidae) et Menetus dilatatus (Gasteropoda, Planorbidae), deux espèces nouvelles pour la faune de France. - Basteria 50: 181-188.

Mouthon, J. \& J. Loiseau (2000): Musculium transversum (Say, 1829): a species new to the fauna of France (Bivalvia, Sphaeriidae). - Basteria 64: 71-77.

Oberdorff, T., B. Hugueny \& J. F. Guégan (1997): Is there an influence of historical events on contemporary fish species richness in rivers? Comparisons between Western Europe and North America. - J. Biogeogr. 24: 461-467.

Parent, G. H. (1981): La découverte lorraine de Craspedacusta sowerbyi Lank. dans son contexte chorologique et écologique européen. - Bull. Soc. Hist. Nat. Moselle 43.

Persat, H. \& P. Keith (1997): La répartition géographique des poissons d'eau douce en France: qui est autochtone et qui ne l'est pas? - Bull. fr. Pêche Piscic. 344/345: 15-32.

Rahel, F. J. (2002): Homogenization of freshwater faunas. - Ann. Rev. Ecol. Syst. 33: 291-315.

Reid, D. F. \& M. I. Orlova (2002): Geological and evolutionary underpinnings for the success of Ponto-Caspian species invasions in the Baltic Sea and North American Great Lakes. - Can. J. Fish. aquat. Sci. 59: 1144-1158.

Remy, P. (1924): Note sur la répartition géographique de Lytogliphus naicoides. - Ann. Biol. lac. 13: 83-91.

Remy, P. (1926): Note sur la distribution géographique de Branchiura sowerbii Beddard. - Ann. Biol. lac. 15: 55-60.

Ricciardi, A. (2001): Facilitative interactions among aquatic invaders: is an "invasional meltdown" occurring in the Great Lakes? - Can. J. Fish. aquat. Sci. 58: 2513-2525.

Ricciardi, A. \& J. B. Rasmussen (1998): Predicting the identity and impact of future biological invaders: a priority for aquatic resource management. - Can. J. Fish. aquat. Sci. 55: 1759-1765.

Rodriguez, S. \& J. P. Vergon (2002): Pectinatella magnifica Leidy 1851 (Phylactolaemates), un bryozoaire introduit dans le nord Franche-Comté. - Bull. fr. Pêche Piscic. 365/366: 281-296.

Rosenfeld, J. S. (2002): Functional redundancy in ecology and conservation. - Oikos 98: 156-162.

Sala, O. E., F. S. Chapin, J. J. Armesto, E. Berlow, J. Bloomfield, R. Dirzo, E. Huber-Sanwald, L.F. Huenneke, R. B. Jackson, A. Kinzig, R. Leemans, D. M. Lodge, H. A. Mooney, M. Oesterheld, N. L. Poff, M. T. Sykes, B. H. Walker, M. Walker \& D. H. Wall (2000): Global biodiversity scenarios for the year 2100. - Science 287: 1770-1774.

Sax, D. F. \& J. H. Brown (2000): The paradox of invasion. - Global Ecol. Biogeogr. 9: 363-371.

Schaffner, F. \& S. Karch (2000): Première observation d'Aedes albopictus (Skuse, 1894) en France métropolitaine. - First record of Aedes albopictus (Skuse, 1894) in metropolitan France. - C. R. Acad. Sci. III - Vie 323: 373-375. 
Simon, K. S. \& C. R. Townsend (2003): Impacts of freshwater invaders at different levels of ecological organisation, with emphasis on salmonids and ecosystem consequences. - Freshwat. Biol. 8: 982-994.

Statzner, B., E. Fievet, J.-Y. Champagne, R. Morel \& E. Herouin (2000): Crayfish as geomorphic agents and ecosystem engineers: biological behavior affects sand and gravel erosion in experimental streams. Limnol. Oceanogr. 45: 1030-1040.

Tachet, E., J. C. Morse \& A. Berly (2001): The larva and Pupa of Pseudoneureclipsis lusitanicus Malicky, 1980 (Trichoptera: Hydropsychoidea): Description, ecological data and taxonomical considerations. - Aquat. Insects 23: 93-106.

Tetry, A. (1939): Contributions à l'étude de la faune de l'Est de la France (Lorraine). - Mémoires de la société des sciences de Nancy 3: 1-453.

Usseglio-Polatera, P., P. Richoux, M. Bournaud \& H. Tachet (2001): A functional classification of benthic macroinvertebrates based on biological and ecological traits: application to river condition assessment and stream management. - Arch. Hydrobiol. 139/1: 53-83.

Van der Velde, G., S. Rajagopal, B. Kelleher, I. B. Muskó \& A. bij de Vaate (2000): Ecological impacts of crustacean invaders: General considerations and examples from the river Rhine. - Crust. Issues 12: 333.

Vanden Bossche, J. P. (2002): First records and fast spread of five new (1995-2000) alien species in the River Meuse in Belgium: Hypania invalida, Corbicula fluminea, Hemimysis anomala, Dikerogammarus villosus and Crangonyx pseudogracilis. - Bull. Inst. r. Sci. nat. Belg. Biol., 72-suppl.: 73-78.

Vermeij, G. J. (1996): An agenda for invasion biology. - Biol. Cons. 78: 3-9.

Vigneux, E. (1997): Les introductions de crustacés décapodes d'eau douce en France. Peut-on parler de gestion? - Bull. fr. Pêche Piscic. 344/345: 357-370.

Vigneux, E., P. Keith \& P. Noël (1993): Atlas préliminaire des Crustacés Décapodes d'eau douce de France. Collection Patrimoines Naturels, Secrétariat Faune-Flore, B.I.M.M.-M.N.H.N., C.S.P., Ministère de l'environnement, Paris, vol. 14: 1-56.

Westman, K. (2002). Alien crayfish in Europe: negative and positive impacts and interactions with native crayfish. - In: Leppäkoski, E., Gollasch, S., \& Olenin, S. (eds.): Invasive aquatic species of Europe. Distribution, Impacts and Management. - Kluwer Academic Publishers, Dordrecht, The Netherlands, pp. 76-95.

Williamson, M. (1996): Biological invasions. - Chapman \& Hall, London.

Wittmann, K. J. \& A. P. Ariani (2000): Limnomysis benedeni: Mysidicé Ponto-Caspien nouveau pour les eaux douces de France (Crustacea, Mysidacea). - Vie Milieu 50: 117-122. 
Table 1. List of 43 non-indigenous species that could be found among French hydrosystems. The functional groups given are from Usseglio-Polatera et al., 2001.

\begin{tabular}{|c|c|c|c|c|c|}
\hline & & & & & \\
\hline & Espèce & Donor Area & $\begin{array}{l}\text { Date of first } \\
\text { observation }\end{array}$ & $\begin{array}{c}\text { Functional } \\
\text { group }\end{array}$ & References \\
\hline Bryozoa & Pectinatella magnifica (Leidy, 1851) & North America & 1994 & $\bar{\zeta}$ & 1,2 \\
\hline \multirow[t]{2}{*}{ Cnidaria } & Cordylophora caspia Pallas, 1771 & Ponto-Caspian & around 1970 & $\zeta$ & 3 \\
\hline & Craspedacusta sowerbyi Lankester, 1880 & South-eastern Asia & 1891 & $\gamma 2$ & $3,4,5,6$ \\
\hline \multirow[t]{2}{*}{ Turbellaria } & Dendrocoelum romanodanubiale Codreanu, 1949 & Ponto-Caspian & around 2002 & $\delta 2$ & 7 \\
\hline & Dugesia tigrina (Girard, 1850) & North America & 1950 & $\gamma 2$ & $3,7,8$ \\
\hline$\overline{\text { Oligochaeta }}$ & Branchiura sowerbyi Beddard, 1892 & South-eastern Asia & before 1926 & $\zeta$ & 3,9 \\
\hline Polychaeta & Hypania invalida (Grube, 1860) & Ponto-Caspian & 1998 & $\bar{\zeta}$ & 7,10 \\
\hline \multirow[t]{2}{*}{ Hirudinae } & Barbronia weberi Blanchard, 1897 & South-eastern Asia & around 2002 & & 7 \\
\hline & Caspiobdella fadejewi Selensky, 1915 & Ponto-Caspian & around 2002 & & 7 \\
\hline \multirow[t]{5}{*}{$\overline{\text { Gastropoda }}$} & Emmerica patula Brumati, 1838 & Central and Eastern Europe & 1981 & & 11 \\
\hline & Lithoglyphus naticoides (C. Pfeiffer, 1828) & Ponto-Caspain & 1909 & $\gamma 1$ & 3,12 \\
\hline & Menetus dilatatus (Gould, 1841) & North America & around 1980 & & 11 \\
\hline & Physella acuta (Draparnaud, 1805) & North America & 1862 & $\gamma 1$ & 3,13 \\
\hline & Potamopyrgus antipodarum Gray, 1843 & New-Zealand & around 1950 & $\zeta$ & 14 \\
\hline \multirow[t]{6}{*}{ Bivalvia } & Anodonta cellensis Schröter, 1779 & Central and Eastern Europe & 1985 & $\zeta$ & 15 \\
\hline & Anodonta woodiana (Lea, 1834) & South-eastern Asia & 1985 & $\zeta$ & 15 \\
\hline & Corbicula fluminalis (Müller, 1774) & South-eastern Asia & 1994 & $\zeta$ & 16 \\
\hline & Corbicula fluminea (Müller, 1774) & South-eastern Asia & 1980 & $\zeta$ & 17,18 \\
\hline & Dreissena polymorpha (Pallas, 1771) & Ponto-Caspian & 1847 & $\zeta$ & 19,20 \\
\hline & Musculium transversum (Say, 1829) & North America & 2000 & $\zeta$ & 21 \\
\hline \multirow[t]{9}{*}{ Amphipoda } & Chelicorophium curvispinum (Sars, 1895) & Ponto-Caspian & 1993 & $\bar{\zeta}$ & $3,16,22$ \\
\hline & Crangonyx pseudogracilis Bousfield, 1958 & North America & 1995 & $\zeta$ & $3,23,22,24$ \\
\hline & Dikerogammarus haemobaphes (Eichwald,1841) & Ponto-Caspian & 1998 & $\zeta$ & 7,25 \\
\hline & Dikerogammarus villosus (Sovinski )Martinov, 1894 & Ponto-Caspian & 1997 & $\zeta$ & $7,10,24,23,22$ \\
\hline & Echinogammarus berilloni (Catta, 1878) & Southern Europe & 1937 & $\zeta$ & 3,26 \\
\hline & Echinogammarus ischnus (Stebbing, 1906) & Ponto-Caspian & 1997 & $\zeta$ & 7 \\
\hline & Gammarus roeselii Gervais, 1835 & Central and Eastern Europe & 1835 & $\beta$ & 27 \\
\hline & Gammarus tigrinus Sexton, 1939 & North America & $1970^{\prime}$ & $\beta$ & 3 \\
\hline & Orchestia cavimana Heller, 1865 & Ponto-Caspian & $1900-1930$ & & 3,28 \\
\hline \multirow[t]{3}{*}{ Isopoda } & Asellus aquaticus (Linnaeus, 1758) & South-eastern Asia & Unknown & $\gamma 2$ & 29 \\
\hline & Jaera istri Veuille, 1979 & Ponto-Caspian & 1999 & $\zeta$ & 7,10 \\
\hline & Proasellus coxalis (Dollfus, 1892) & Southern Europe & 1930 & $\gamma 2$ & 7,29 \\
\hline \multirow[t]{9}{*}{$\overline{\text { Decapoda }}$} & Astacus leptodactylus Eschscholtz, 1823 & Central and Eastern Europe & 1890 & $\gamma 2$ & 30,31 \\
\hline & Atyaephyra desmaresti (Millet, 1831-1832) & Southern Europe & 1832 & $\gamma 2$ & 3,30 \\
\hline & Eriocheir sinensis Milne-Edwards, 1853 & South-eastern Asia & 1930 & $\gamma 2$ & 32 \\
\hline & Hemimysis anomala Sars, 1907 & Ponto-Caspian & 2000 & & 7,27 \\
\hline & Limnomysis benedeni Czerniavsky, 1882 & Ponto-Caspian & 2000 & & 7,33 \\
\hline & Orconectes limosus (Rafinesque, 1817) & North America & 1912 & $\gamma 2$ & $30,32,31$ \\
\hline & Pacifastacus leniusculus (Dana, 1852) & North America & 1973 & $\delta 2$ & $30,31,34$ \\
\hline & Potamon ibericum tauricium (Czerniavsky, 1884) & Southern Europe & 1991 & $\gamma 2$ & 30,35 \\
\hline & Procambarus clarkii (Girard, 1852) & North America & 1976 & $\delta 1$ & 30,31 \\
\hline$\overline{\text { Diptera }}$ & Aedes albopictus Skuse, 1894 & South-eastern Asia & 1999 & $\delta 1$ & 36 \\
\hline$\overline{\text { Trichoptera }}$ & Pseudoneureclipsis lusitanicus Malicky, 1980 & Southern Europe & 2001 & $\zeta$ & 37 \\
\hline
\end{tabular}

1: d'Hondt \& Condé, 1996; 2: Rodriguez \& Vergon, 2002; 3: Dhur \& Massard, 1995; 4: Parent, 1981; 5: Arvy, 1972; 6: Goy, 1971; 7: Anonymous, 2002; 8: Hoffman 1964; 9: Remy, 1926; 10: Devin et al. , in press; 11: Mouthon, 1986; 12: Remy, 1924; 13: Godron, 1862; 14: Boettger, 1954; 15: Girardill \& Ledoux, 1989; 16: Bachmann et al., 1997; 17: Fontan \& Meny, 1997; 18: Mouthon, 1981; 19: Kinzelbach, 1992; 20: Léglize \& Ollivier, 1981 ;21: Mouthon \& Loiseau, 2000; 22: Lécureuil \& Chovet, 2003; 23: Bollache et al., 2004; 24: Vandenbossche, 2002; 25: Devin et al., 2001; 26: Kinzelbach, 1972; 27: Jazdzewski, 1980; 28: Tetry, 1939; 29: Henry \& Magniez, 1983; 30: Vigneux, 1997; 31: Laurent, 1997; 32: André, 1934; 33: Wittman \& Ariani, 2000; 34: Vigneux et al. , 1993; 35: Charmantier, 1992; 36: Schaffner \& Karch, 2000; 37: Tachet et al., 2001 
Table 2. Proportion of non-indigenous fauna among French macroinvertebrate fauna in freshwater systems. The total number of macroinvertebrate species in French freshwaters are unpublished results. Nematomorpha and parasites were excluded.

\begin{tabular}{lrrr} 
& $\begin{array}{c}\text { Total number } \\
\text { of species }\end{array}$ & $\begin{array}{c}\text { Number of } \\
\text { exotic species }\end{array}$ & $\begin{array}{c}\text { Percentage of } \\
\text { exotic species }\end{array}$ \\
\hline Bryozoa & 11 & 1 & 9.1 \\
Porifera & 5 & 0 & 0 \\
Cnidaria & 8 & 2 & 25 \\
Platyhelminthes & 33 & 2 & 6.1 \\
Hirudinea & 16 & 2 & 12.5 \\
Oligochaeta & 147 & 1 & 0.7 \\
Polychaeta & 1 & 1 & 100 \\
Bivalvia & 33 & 6 & 18.2 \\
Gastropoda & 55 & 5 & 9.1 \\
Crustacea & 86 & 21 & 24.4 \\
Insecta & 3257 & 2 & 0.06 \\
\hline
\end{tabular}

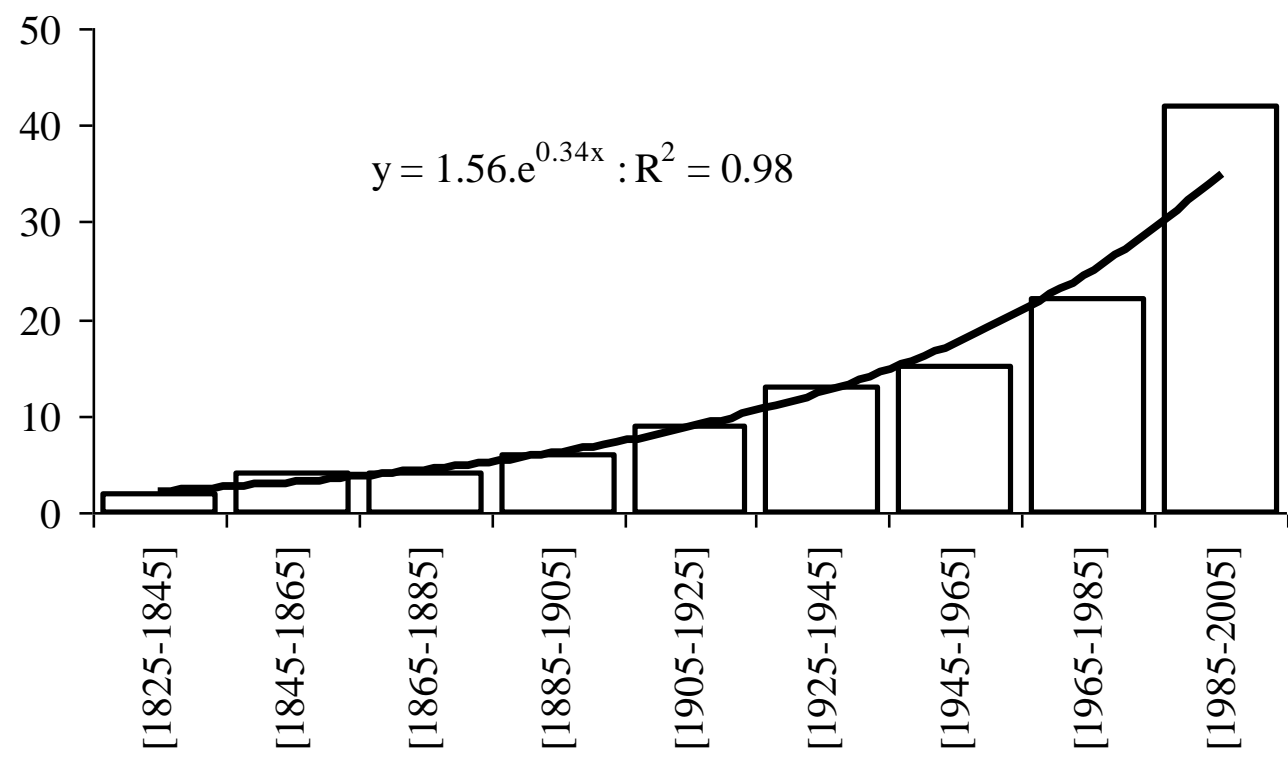

Figure 1: Trend in cumulative number of species established in French aquatic ecosystems. Three functions were tested, and the exponential one gave the best fit with our date. Only 42 species were considered in this analysis, as the date of arrival of Asellus aquaticus is not precisely known. Linear and power function relationships were also tested, but exhibit a lower correlation with the observed trend $\left(R^{2}=0.77\right.$ and $R^{2}=0.89$ respectively). 